\title{
Ernæringstilskudd bedret funksjon etter slag
}

Utvalg og oversettelse ved Liv Merete Reinar

Illustrasjonsfoto: Colourbox

Vil forsterket ernæringstilskudd bedre funksjon hos underernærte slagpasienter i slagrehabiliteringsavdelinger?

\section{METODE}

Design: Randomisert, kontrollert studie.

Allokering: Skjult.

Blinding: Blindet (pasient, helsepersonell, terapeuter, datainnhenter og utfallsmåler).

Oppfølgingstid: Til utskrivelse (gjennomsnitt 26 dager).

Setting: Slagrehabiliteringsavdeling i New York, USA.

Pasienter: 116 pasienter (gjennomsnittsalder 74 år, 59 prosent menn) som hadde sitt første slag < fire uker før innleggelse, hadde 2,5 prosent vektreduksjon innen to uker etter slaget, var medisinsk stabile og kunne ta til seg oral ernæring. Eksklusjonskriterier var demens, alkoholmisbruk, nyreeller leversykdom, malabsorpsjon, og terminal sykdom.

Intervensjon: Forsterket ernæringstilskudd (240 kalorier, 11 gram protein) ( $\mathrm{n}=58)$ eller standard ernæringstilskudd (127 kalorier, 5 gram protein) ( $\mathrm{n}=58), 120$ $\mathrm{ml}$ hver åttende time til utskriving, samt vanlig sykehuskost og multivitaminer.

Utfall: Endring i «Functional Independence Measure» (FIM) total skår, FIM motorisk og kognitiv subskår, to og seks minutters gåtest, tidsrom for innleggelse og utskriving til hjemmet.

Pasientoppfølging: 88 prosent (intention-to-treat analyse).

\section{HOVEDRESULTATER}

Pasienter som fikk forsterket ernæringstilskudd hadde større bedring i total FIM-skår, motorisk FIM-skår og for to og seks minutters gåtest (tabell). Det var ingen forskjell mellom gruppene når det gjaldt endringer i kognitiv FIM-skår (tabell), vektøkning eller hvor lenge de var innlagt i avdelingen. Flere pasienter som fikk forsterket ernæringstilskudd ble utskrevet til hjemmet (63 prosent versus 43 prosent, $\mathrm{p}<0,05)$.

\section{KONKLUSJON}

Forsterket ernæringstilskudd bedret funksjon mer enn standard tilskudd hos underernærte slagpasienter i slagrehabiliteringsavdeling.

Sammendrag fra: Rabadi $\mathrm{MH}$, Coar PL, Lukin M, et al. Intensive nutritional supplements can imrpove outcomes in stroke rehabilitation. Neurology 2008; 71: 1856-61.

Korrespondanse til: $\mathrm{Dr} \mathrm{MH}$ Rabadi, VA Medical Center, Oklahoma City, OK, USA: mhrabadi@gmail.com

Finansiering: Burke Medical Research Foundation og Novartis.

TABELL: Forsterket versus standard ernæringstilskudd hos underernærte slagpasienter*

\begin{tabular}{lcccrr}
\hline \multicolumn{5}{c}{ Gjennomsnittlig endring ved utskrivelse } & \\
\hline Utfall & $\begin{array}{c}\text { Gjennomsnitt skår } \\
\text { ved innleggelse }\end{array}$ & $\begin{array}{c}\text { Forsterket } \\
\text { tilskudd }\end{array}$ & $\begin{array}{c}\text { Standard } \\
\text { tilskudd }\end{array}$ & Endring** & p-verdi \\
\hline Total FMI skår & 47 & 31 & 23 & 8,6 & 0,001 \\
\hline Motor FIM sub-skår & 27 & 24 & 17 & 7,5 & 0,001 \\
\hline Kognitiv FIM sub-skår & 19 & 4,6 & 4,4 & 0,2 & 0,80 \\
\hline 2-min gåtest & 45 & 102 & 44 & 58 & $<0,001$ \\
\hline 6-min gåtest & 100 & 299 & 171 & 129 & $<0,001$ \\
\hline
\end{tabular}

*FIM, Functional Independence Measure (18 punkter, range 18 til 126 [best]), motorisk FIM subskår (13 punkter, range 13 til 91), kognitiv FIM subskår (5 punkter, range 5 til 35).

**En positiv forskjell går i favør av intensivt ernæringstilskudd. 
$=$

Evidence-Based Nursing

BMJIJournals

.
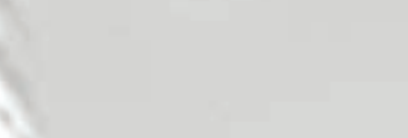

.

.

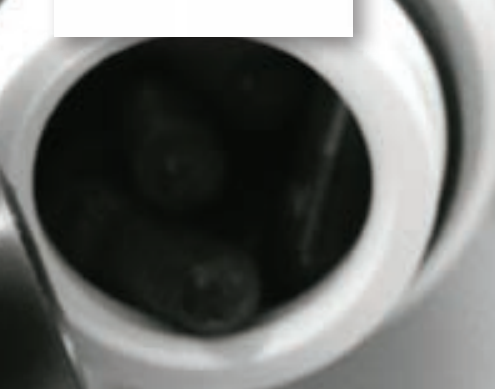

$\AA$ bedre ernæringsstatus etter slag kan være vanskelig på grunn av problemer med motorikk, svelging, kognitiv svikt og emosjonell status. Den store «FOOD trial» ga ikke støtte for proteinbasert ernæringstilskudd etter slag; selv om en undergruppe av pasienter med dårlig ernæringsstatus så ut til å ha positiv effekt av et slikt tiltak (1). Én observasjonsstudie har vist at pasienter med alvorlig slag som fikk enteral ernæring i rehabiliteringsfasen hadde bedre funksjon (2). I lys av disse funnene unders $\varnothing$ kte Rabadi og medarbeidere underernærte pasienter som var innlagt i en slagrehabiliteringsavdeling.

Styrken ved denne studien er blant annet randomisert fordeling, bruk av standard tilskudd i kontrollgruppen og blinding av utfallsmåler. Hver tilskuddsdose hadde lavt volum $(120 \mathrm{ml})$ og ble gitt av sykepleier som noterte at tilskuddet ble tatt. Betenkeligheter ved studien er blant annet lav terskel for å definere underernæring og mangel på informasjon om ernæring ved baseline og hydreringsstatus. Det ble heller ikke rapportert noen mål for alvorlighetsgraden av slag (som er en sterk prognostisk faktor) og det er derfor vanskelig å vurdere om baselinerisiko var lik mellom gruppene. Allokering til tiltaket var blindet, men forskjell mellom smak, konsistens, tekstur og konsistens kan være observert av helsepersonell.

Selv om det kan settes spørsmål ved forskningsprotokollen og resultatene står i kontrast til funnene fra den større «FOOD trial» (1), vil funnene fra Rabadi støtte det å tilby forsterket ernæringstilskudd til underernærte pasienter som skal rehabiliteres etter slag. Pasienter som fikk forsterket tilskudd gjorde større framskritt med tanke på motorisk funksjon enn de som fikk standard behandling, og det var større sjanse for at de ble utskrevet til hjemmet. Ernæring er viktig for immunitetsforsvar og gir energi til fysisk trening og heling. Tilskudd kan være særlig viktig når skader som er assosiert med slag og slagrehabilitering gjør det vanskelig å spise tilstrekkelig for å få nok næring. Forsterket tilskudd gir pasienter tilgang på ernæringsstoffer uten at det kreves appetitt og evne til å spise større måltider.

Nancy Bergstrom, RN, PhD, FAAN. University of Texas School of Nursing Houston, Houston, Texas, USA.

1. FO0D Trial Collaboration. Lancet 2005; 365: 755-63

2. James R, Gines D, Menlove A, et al. Arch Phys Med Rehabil 2005; 86 (Suppl 2): S82-92.

(C) Evidence Based Nursing (EBN) juli 2009 vol 12 no 3

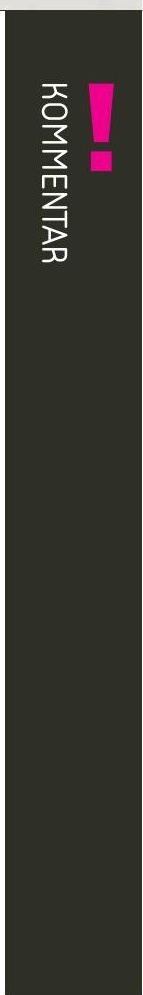

